\title{
STUDI PEMANFAATAN ENERGI MATAHARI SEBAGAI SUMBER ENERGI ALTERNATIF TERBARUKAN BERBASIS SEL FOTOVOLTAIK UNTUK MENGATASI KEBUTUHAN LISTRIK RUMAH SEDERHANA DI DAERAH TERPENCIL
}

\author{
${ }^{(1)}$ Hasbi Assiddiq S, ${ }^{(2)}$ Irma Dinahkandy \\ (1)(2) Jurusan Teknik Mesin, Politernik Kotabaru \\ JI. Raya Stagen Km. 8,5 Kotabaru Kalimantan Selatan \\ Email: hasbiassiddiq999@gmail.com
}

\begin{abstract}
ABSTRAK
Radiasi matahari global di Indonesia adalah 1700-1950 $\mathrm{kWh} / \mathrm{m}^{2} /$ tahun $=4$,66$5,34 \mathrm{kWh} / \mathrm{m}^{2} /$ hari. Sehingga perlu dilakukan upaya untuk memanfaatkan potensi energi matahari menjadi energi listrik, khususnya kawasan pemukiman di daerah terpencil dan belum terjangkau jaringan listrik PLN. Penelitian ini bertujuan untuk ; mengetahui jumlah daya yang dibutuhkan oleh masyarakat untuk penerangan dan penggunaan peralatan elektronik di setiap rumah sederhana di daerah terpencil (studi kasus di Desa Oka-oka), memperoleh desain sistem tenaga surya independen untuk memenuhi kebutuhan listrik setiap rumah sederhana di daerah terpencil, dan mengetahui perkiraan total anggaran untuk pembangunan sistem tenaga surya secara mandiri dari skala rumah sederhana di daerah terpencil. Hasil perhitungan jumlah kebutuhan listrik per hari adalah $1396 \mathrm{Wh} /$ hari. Total anggaran yang digunakan untuk pembangunan sistem sederhana adalah Rp. 12.000 .000 atau Rp. 200.000 per bulan dengan lama pemakaian rata-rata 5 tahun.
\end{abstract}

Kata Kunci : Sel fotovoltaik, tegangan, energi matahari, daya, radiasi

\section{PENDAHULUAN}

Rasio elektrifikasi Indonesia saat ini adalah $87 \%$, hal tersebut menunjukkan 8,5 juta penduduk Indonesia atau sekitar 2500 desa yang belum dialiri listrik [1]. Sedangkan rasio elektrifikasi untuk Kalimantan Selatan adalah 84\%, artinya masih tersisa $16 \%$ rumah tangga di wilayah ini yang belum menikmati aliran listrik. Di daerah Kabupaten Kotabaru terdapat beberapa desa terpencil yang belum menikmati aliran listrik, karena lokasinya yang jauh dari wilayah perkotaan, ada juga yang jarak antara satu rumah dengan rumah lainnya sangat berjauhan, selain itu terdapat juga pemukiman di pulaupulau kecil sehingga sangat sulit bagi jaringan listrik PLN untuk menjangkaunya.

Indonesia merupakan negara tropis dimana daerahnya dilalui oleh garis khatulistiwa sehingga memiliki potensi menerima panas matahari yang besar. Berdasarkan gambar 1 penyinaran matahari global di Indonesia yaitu $1700-1950 \mathrm{kWh} / \mathrm{m}^{2} /$ tahun $=4,66-5,34$ $\mathrm{kWh} / \mathrm{m}^{2} /$ hari [2]. Pemanfaatan energi matahari sebagai sumber daya bebas polusi dan berlimpah, terbarukan, yang dapat digunakan baik secara langsung maupun tidak langsung. Energi matahari dapat digunakan sebagai pemanas langsung, memanaskan air dan udara dengan solar kolektor, serta penyediaan listrik dengan sel fotovoltaik. Beberapa 
kelebihan energi terbarukan antara lain: sumbernya relatif mudah didapat, dapat diperoleh dengan gratis, minim limbah, tidak mempengaruhi suhu bumi secara global, dan tidak dipengaruhi oleh kenaikan bahan bakar.

Tidak diragukan lagi bahwa energi matahari adalah salah satu sumber energi yang ramah lingkungan dan sangat menjanjikan pada masa yang akan datang, karena tidak ada polusi yang dihasilkan selama proses konversi energi, dan juga sumber energinya banyak tersedia di alam. PLTS atau lebih dikenal dengan sel surya (sel fotovoltaik) akan lebih diminati karena dapat digunakan untuk berbagai keperluan yang relevan dan di berbagai tempat seperti perkantoran, pabrik, perumahan, dan lainnya [3].

Penelitian ini dilakukan sebagai bentuk dukungan dalam upaya memanfaatkan potensi Energi Baru dan Terbarukan (EBT) sesuai dengan program pemerintah. Pemanfaatan energi terbarukan lokal yang dinilai ramah lingkungan dan dapat digunakan bagi daerah terpencil dan terluar khususnya yang belum terjangkau oleh sistem interkoneksi jaringan PLN. Berdasarkan hal tersebut maka dipandang perlu melakukan studi pemanfaatan energi matahari di Kabupaten Kotabaru sebagai sumber energi listrik terbarukan berbasis sel fotovoltaik untuk mengatasi kebutuhan listrik di daerah terpencil.

\section{METODE PENELITIAN \\ Waktu dan Tempat.}

Penelitian/ pengambilan data dilaksanakan pada bulan Agustus 2018 di Desa Oka-oka Kecamatan Pulau Laut Kepulauan Kabupaten Kotabaru Propinsi Kalimantan Selatan Indonesia.

Jenis data yang digunakan dalam penelitian ini adalah data kualitatif dan kuantitatif. Data kualitatif yaitu data yang disajikan dalam bentuk kata verbal bukan dalam bentuk angka. Adapun yang termasuk data kualitatif dalam penelitian ini yaitu gambaran umum tentang pembangkit listrik tenaga surya, sejarah singkat tentang sel fotovoltaik, serta keadaan masyarakat setempat. Data kuantitatif adalah jenis data yang dapat diukur atau dihitung secara langsung yang berupa informasi atau penjelasan yang dinyatakan dengan bilangan atau berbentuk angka. Adapun yang termasuk data kuantitatif yaitu besarnya kebutuhan daya listrik rumah sederhana di Desa Oka-oka, intensitas radiasi matahari, arus dan tegangan keluaran sel fotovoltaik, jumlah biaya yang digunakan untuk pembangunan sistem pembangkit listrik tenaga surya untuk rumah sederhana.

\section{Tahapan Rancangan Sistem.}

Menghitung total daya beban pemakaian per hari, menentukan ukuran kapasitas sel fotovoltaik yang sesuai dengan beban pemakaian, menentukan kapasitas baterai/aki, analisa hasil dan evaluasi.

Penelitian mulai dilakukan dengan wawancara kepada warga di Desa Oka-oka tentang rencana kebutuhan konsumsi daya listrik untuk penerangan dan peralatan elektronik lainnya, lalu pembuatan rangka dudukan sel fotovoltaik yang akan digunakan untuk pengujian. Kemudian menghubungkan setiap komponenkomponen seperti sel fotovoltaik, solar charger chontroller, inverter, baterai dan beban serta alat ukur (multimeter dan pyranometer). Pengambilan data dilakukan setiap jam mulai dari pukul 08.00 Wita sampai dengan pukul 16.00 Wita dengan cara mencatat variabel pengukuran berupa intensitas radiasi matahari, tegangan, dan arus keluaran sel fotovoltaik. Data-data tersebut diperlukan untuk menghitung potensi energi rata-rata yang dapat dimanfaatkan di Desa Oka-oka berupa besarnya fill factor, daya keluaran, daya masuk dan efisiensi sel fotovoltaik. Analisis dilakukan dengan mengacu pada data hasil wawancara terhadap warga dan potensi energi matahari di Desa Oka-oka.

\section{Prinsip Kerja Sel Fotovoltaik.}

Sel fotovoltaik bekerja berdasarkan efek fotoelektrik pada material semikonduktor untuk mengubah energi cahaya menjadi energi listrik. Berdasarkan teori Maxwell tentang radiasi elektromagnet, cahaya dapat 
p-ISSN 2502-4922,e-ISSN 2615-0867

maskimum yang diperoleh pada pukul 12.00 WITA. Setelah itu daya keluaran $P_{\text {out }}(W)$ sel fotovoltaik akan mengalami penurunan mengikuti nilai daya masuk $P_{\text {in }}(W)$ yang juga telah mengalami penurunan mulai pada pukul 13.00 hingga 16.00 WITA. Adapun nilai daya masuk $P_{\text {in }}$ pada pukul 08.00 WITA adalah $126,729 \mathrm{~W}$ dengan daya keluaran $P_{\text {out }}$ sel fotovoltaik sebesar $15,372 \mathrm{~W}$ dan pada pukul 12.00 WITA daya masuk $P_{\text {in }}$ adalah 299,513 W dengan daya keluaran $P_{\text {out }}$ sebesar 41,804 $W$ dan pada pukul 16.00 WITA daya masuk $P_{\text {in }}$ adalah $151,638 \mathrm{~W}$ serta daya keluaran $P_{\text {out }}$ yang diperoleh sebesar 20,045 W seperti yang diperlihatkan pada tabel hasil perhitungan (Tabel 1) dan gambar 1 di bawah ini.

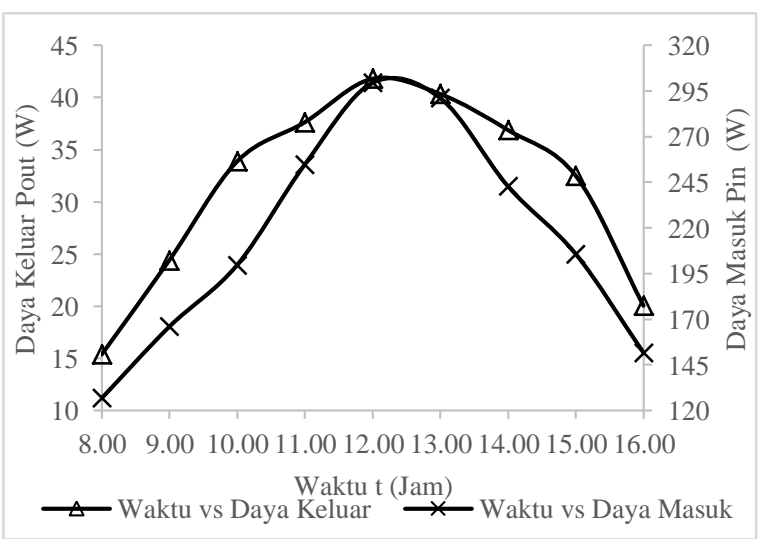

Gambar 1. Grafik hubungan antara Waktu

$(t)$ vs Daya Masuk $P_{i n}(W)$ dan Daya Keluar $P_{\text {out }}(W)$

Hasil perhitungan memperlihatkan bahwa besarnya daya maksimum $P_{m}(W)$ keluaran sel fotovoltaik bergantung pada besarnya daya masuk $P_{i n}(W)$ ke sel fotovoltaik, dimana daya masuk $P_{i n}(W)$ sangat bergantung pada waktu penyinaran matahari. Daya masuk $P_{i n}(W)$ terbesar diperoleh pada pukul 12.00 WITA yaitu $299,513 \mathrm{~W}$ dan daya keluaran maksimum $P_{m}(W)$ diperoleh juga pada pukul 12.00 WITA sebesar 41,804 W. Namun berbeda dengan nilai efisiensi maksimum $\eta_{m}$ (\%) yang diperoleh pada pukul 10.00 WITA yaitu $16,965 \%$ sedangkan pada pukul 12.00 nilai efisiensi $\eta$ (\%) sel fotovoltaik yang diperoleh adalah $13,958 \%$ yang dapat dilihat pada tabel 1 hasil perhitungan serta pada gambar 2 .

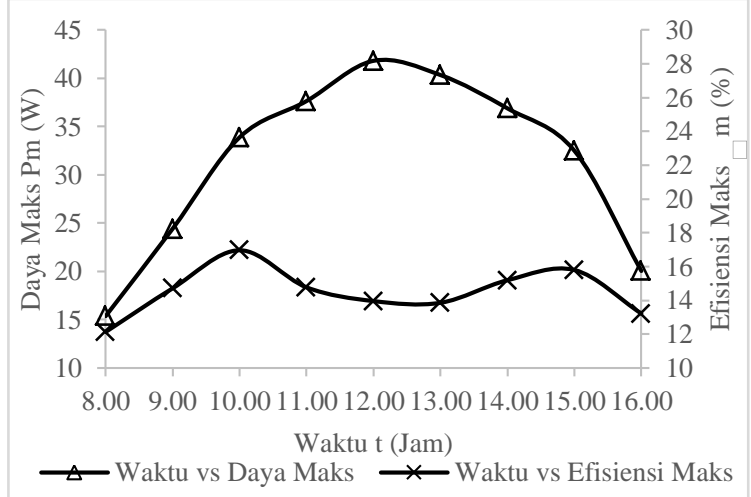

Gambar 2. Grafik hubungan antara Waktu

$(t)$ vs Daya $P_{m}(W)$ dan Efisiensi $\eta_{m}(\%)$

Rancangan Pembangkit Listrik Tenaga Surya (PLTS).

Pembangkit listrik tenaga surya ini dirancang mengacu pada hasil wawancara dengan warga masyarakat di Desa Oka-oka agar kebutuhan daya listrik rumah tinggal sederhana di daerah tersebut dapat terpenuhi. Adapun total kebutuhan daya listrik rumah tinggal warga di Desa Oka-oka diperlihatkan dalam tabel 2 .

Tabel 2 hasil perhitungan total daya pemakaian setiap rumah per hari dapat diperoleh dari jumlah keseluruhan beban pemakaian yaitu $=1396 \mathrm{Wh} / \mathrm{hari}$, karena rangkaian instalasi juga membutuhkan daya pada saat beroperasi maka total daya beban pemakaian ditambahkan $10 \%$ sehingga total beban pemakaian menjadi; $1396+139,6=$ 1535,6 Wh/hari.

Sel fotovoltaik yang rencana akan digunakan pada sistem ini adalah sel fotovoltaik kapasitas $50 \mathrm{Wp}$ dengan asumsi penyinaran matahari yaitu $9 \mathrm{Jam} / \mathrm{hari}$, sehingga jumlah sel fotovoltaik yang dibutuhkan untuk memenuhi kebutuhan daya setiap rumah tinggal di Desa Oka-oka adalah sebagai berikut:

$$
\begin{aligned}
S_{f} & =\frac{1535,6}{(50 \times 9)} \\
& =\frac{1535,6}{450}
\end{aligned}
$$

$=3,41 \approx 4$ buah panel

Jumlah kebutuhan baterai 12 Volt dengan kapasitas masing-masing $300 \mathrm{Ah}$. Kebutuhan baterai minimum (daya baterai hanya digunakan sekitar 50\% untuk pemenuhan kebutuhan listrik), sehingga kebutuhan daya 
akan dikalikan 2 x lipat, 1535,6 x $2=3071,2$ Wh.

$$
\begin{aligned}
S_{B} & =\frac{3071,2}{(12 \times 300} \\
& =\frac{3071,2}{3600} \\
& =0,85 \approx 1 \text { Baterai } 300 \mathrm{Ah}
\end{aligned}
$$

\begin{tabular}{|c|c|c|c|c|}
\hline No & Nama & $\begin{array}{l}\text { Daya } \\
\text { setiap } \\
\text { Beban } \\
\text { (Watt) }\end{array}$ & $\begin{array}{l}\text { Lama } \\
\text { (h/hari) }\end{array}$ & $\begin{array}{c}\text { Beban } \\
\text { (Wh/hari) }\end{array}$ \\
\hline 1 & $\begin{array}{l}\text { Lampu } \\
\text { LED }\end{array}$ & 5 & 6 & 180 \\
\hline 2 & $\begin{array}{l}\text { Pompa } \\
\text { Air }\end{array}$ & 75 & 1 & 75 \\
\hline \multirow{2}{*}{3} & \multirow{2}{*}{$\begin{array}{l}\text { Mesin } \\
\text { Cuci }\end{array}$} & $\begin{array}{c}\text { Cuci } \\
\text { bilas } 85\end{array}$ & 1 & 85 \\
\hline & & $\begin{array}{c}\text { Kering } \\
40\end{array}$ & 0,5 & 20 \\
\hline 4 & $\begin{array}{l}\text { Televisi/ } \\
\text { TV LED }\end{array}$ & 28 & 5 & 140 \\
\hline 5 & $\begin{array}{l}\text { Receiver } \\
\text { Parabola }\end{array}$ & 20 & 5 & 100 \\
\hline 6 & $\begin{array}{l}\text { Rice } \\
\text { Cooker }\end{array}$ & 50 & 1 & 50 \\
\hline 7 & Dispenser & 80 & 1 & 80 \\
\hline 8 & $\mathrm{HP}$ & 4 & 3 & 36 \\
\hline 9 & Setrika & 100 & 1 & 100 \\
\hline \multirow{2}{*}{10} & \multirow{2}{*}{ Kulkas } & $\begin{array}{c}\text { Nyala } \\
50\end{array}$ & 2 & 100 \\
\hline & & $\begin{array}{c}\text { Standby } \\
10\end{array}$ & 22 & 220 \\
\hline 11 & $\begin{array}{l}\text { Kipas } \\
\text { Angin } \\
\end{array}$ & 35 & 3 & 210 \\
\hline \multicolumn{4}{|c|}{$\begin{array}{r}\text { Total daya beban pemakaian per hari } \\
\text { (Wh/hari) }\end{array}$} & 1396 \\
\hline \multicolumn{4}{|c|}{$\begin{array}{r}\text { Total daya beban pemakaian per hari } \\
+10 \%(\text { Wh/hari })\end{array}$} & 1535,6 \\
\hline
\end{tabular}

Tabel 2. Tabel perhitungan total kebutuhan daya rumah tinggal sederhana

\begin{tabular}{|c|c|}
\hline $\begin{array}{r}\text { Biaya investasi pembangunan } \\
\text { PLTS per } 5 \text { Tahun }\end{array}$ & 12.000 .000 \\
\hline $\begin{array}{r}\text { Besarnya biaya rata-rata per } \\
\text { selama } 5 \\
\end{array}$ & \\
\hline
\end{tabular}

Tabel 3. Total biaya PLTS secara mandiri

\begin{tabular}{|c|l|c|c|c|}
\hline No & $\begin{array}{l}\text { Jenis } \\
\text { Barang }\end{array}$ & $\begin{array}{l}\text { Spesifi } \\
\text { kasi }\end{array}$ & Jumlah & $\begin{array}{c}\text { Jumlah } \\
(\boldsymbol{R} \boldsymbol{p})\end{array}$ \\
\hline 1 & $\begin{array}{l}\text { Sel } \\
\text { Fotovolt } \\
\text { aik }\end{array}$ & $50 \mathrm{Wp}$ & 4 & 4.000 .000 \\
\hline 2 & Baterai & $\begin{array}{l}12 \quad \mathrm{~V} \\
300 \mathrm{Ah}\end{array}$ & 2 & 6.000 .000 \\
\hline 3 & $\begin{array}{l}\text { Kontroll } \\
\text { er }\end{array}$ & $10 \mathrm{~A}$ & 1 & 500.000 \\
\hline 4 & Inverter & $\begin{array}{l}12 \\
V D C \\
2000 \mathrm{~W}\end{array}$ & 1 & 1.000 .000 \\
\hline 5 & Instalasi & - & 1 & 500.000 \\
\hline
\end{tabular}

Karena kondisi cuaca yang biasa mendung, maka dipertimbangkan baterai dapat memenuhi kebutuhan selama 2 hari tanpa sinar matahari. Sehingga kebutuhan daya menjadi 1535,6 × 2 × $2=6142,4 \mathrm{Wh}$. Maka kebutuhan baterai untuk sistem adalah:

$$
\begin{aligned}
S_{B} & =\frac{6142,4}{(12 \times 300)} \\
& =\frac{6142,4}{3600} \\
& =1,71 \approx 2 \text { baterai } 300 \mathrm{Ah}
\end{aligned}
$$

\section{Jumlah Biaya PLTS Secara Mandiri.}

Berdasarkan hasil perhitungan setiap komponen pembangkit listrik tenaga surya, maka total biaya yang dibutuhkan untuk membangun suatu sistem pembangkit listrik tenaga surya yang dapat memenuhi kebutuhan energi listrik pada setiap rumah tinggal sederhana di Desa Oka-oka diperlihatkan dalam tabel 3 .

Dari hasil perhitungan dapat diketahui bahwa total daya yang diperlukan sebesar 1535,6 W, dengan jumlah sel fotovoltaik 4 unit (masing-masing $50 \mathrm{WP}$ ) dan kebutuhan baterai sebanyak 2 Unit (12 Volt $300 \mathrm{Ah}$ ). Dari rancangan yang dilakukan maka total biaya yang harus diinvestasikan dapat diperoleh seperti yang diperlihatkan pada tabel 5 (ditentukan 5 tahun karena baterai maksimal dapat digunakan selama 5 tahun). Sehingga nilai investasi dalam jangka waktu 5 tahun adalah Rp, 12.000.000 dengan perhitungan perbulannya Rp. 200.000 .

\section{KESIMPULAN}

Berdasarkan hasil wawancara terhadap warga di Desa Oka-oka dan pengujian serta analisa yang telah dilakukan, maka dapat ditarik beberapa kesimpulan yaitu :

1. Dari hasil wawancara tentang peralatan elektronik yang rencana akan digunakan 
oleh warga di Desa Oka-oka dan hasil perhitungan, maka total daya kebutuhan untuk setiap rumah tinggal sederhana di Desa Oka-oka per hari yaitu 1396 Wh/hari.

2. Rancangan sistem pembangkit listrik tenaga surya (PLTS) mandiri untuk rumah tinggal sederhana di Desa Okaoka diperoleh berdasarkan total daya kebutuhan dengan mempertimbangkan cuaca dan kebutuhan daya pada sistem yang meliputi komponen sel fotovoltaik $50 \mathrm{Wp}$ (4 panel), baterai 12 VDC $300 \mathrm{Ah}$ (2 unit), Solar Charger Controller $10 A$ (1 Unit), Inverter 12 VDC 2000 W (1 unit), dan instalasi.

3. Adapun estimasi total anggaran yang diinvestasikan untuk pembangunan sistem pembangkit listrik tenaga surya skala rumah tinggal sederhana di Desa Oka-oka adalah $R p 12.000 .000$ atau $R p$ 200.000 per bulan dengan lama pemakaian sistem pembangkit listrik tenaga surya secara efektif adalah 5 tahun karena komponen baterai rata-rata umur pemakaiannya selama 5 tahun.

\section{REFERENSI}

[1] Putra, S., dan Rangkuti, Ch., 2016. Perencanaan Pembangkit Listrik Tenaga Surya Secara Mandiri Untuk Rumah Tinggal. Seminar Nasional Cendekiawan, Fakultas Teknologi Industri, Universitas Trisakti.

[2] Permana, Imam., 2008. Pengenalan Teknologi Tenaga Surya. Modul, Bandung: PPPPTK.

[3] Ramadhan, A.I., dkk., 2016. Analisis Desain Sistem Pembangkit Listrik Tenaga Surya Kapasitas 50 WP. Teknik Mesin, Fakultas Teknik, Universitas Muhammadiyah Jakarta. Teknik, 37(2), Jakarta, 59-63.

[4] Gunardi, Y., 2010. Perancangan dan Pembuatan Pembangkit Listrik Tanaga Matahari untuk Lampu Penerang Jalan. Jurnal Energi,Teknik Elektro, Fakultas Teknologi Industri, Universitas Mercu Buana, Jakarta, Vol. 14, No. 1, 63-68.

[5] Rahayuningtyas, A., dkk., 2014. Studi Perencanaan Sistem Pembangkit Listrik enaga Surya (PLTS) Skala Rumah Sederhana Di Daerah Pedesaaan
Sebagai Pembangkit Listrik Alternatif Untuk Mendukung Program Ramah Lingkungan Dan Energi Terbarukan. Prosiding SnaPP 2014 Sains, Teknologi, dan Kesehatan. Vol. 4, No. 1, 223-230

[6] Kalogirou, S. A., 2009. Solar Energy Engineering Proses and Systems. 1 st penyunt. America: Elsevier Inc. All rights reserved

Diputra, dan Wibeng., 2008. Simulator Algoritma Pendeteksi Kerusakan Modul Surya pada Rangkaian Modul Surya. Tesis, Universitas Indonesia, Jakarta. 